\section{Validity of physical activity and food consumption questionnaire for children aged seven to ten years old}

\section{Validação de um questionário de atividade física e consumo alimentar para crianças de sete a dez anos de idade}

\author{
Mauro V. G. Barros 1 \\ Maria Alice A. de Assis 2 \\ Mário C. Pires 3 \\ Suely Grossemann 4 \\ Francisco de Assis G. de Vasconcelos 5 \\ Maria Elizabeth Peixoto Luna 6 \\ Simone S. Honda Barros 7 \\ 1,7 Grupo de Pesquisa em Estilos de Vida e Saúde. Programa de \\ Pós-Graduação em Hebiatria Escola Superior de Educação Física. \\ Universidade de Pernambuco. Rua Arnóbio Marques, 310. Recife, \\ PE, Brasil. CEP: 50.100-130 E-mail: mauro@esef.upe.br \\ 2,5 Departamento de Nutrição da Universidade Federal de Santa \\ Catarina.Florianópolis, SC, Brasil \\ 3 Colégio de Aplicação. Universidade Federal de Santa Catarina. \\ Florianópolis, SC, Brasil. \\ 4 Departamento de Pediatria. Universidade Federal de Santa \\ Catarina. Florianópolis, SC, Brasil \\ 6 Secretaria de Saúde da Prefeitura Municipal de Florianópolis. \\ Florianópolis, SC, Brasil \\ 7 Núcleo de Pesquisa em Atividade Física e Saúde. Programa de \\ Pós-Graduação em Educação Física da Universidade Federal de \\ Santa Catarina. Florianópolis, SC, Brasil
}

\section{Resumo}

Objetivos: avaliar a reprodutibilidade e validade concorrente do questionário dia típico de atividade física e alimentação (DAFA) para medida de atividade física $e$ consumo alimentar em crianças de sete a dez anos.

Métodos: participaram do estudo 69 crianças recrutadas em escola pública de Florianópolis. A reprodutibilidade foi determinada comparando medidas de duas aplicações do DAFA com intervalo de duas semanas, enquanto a validade concorrente das medidas de atividade física foi analisada comparando DAFA com questionário respondido por pais/professores. Quanto ao consumo alimentar, o método de referência foi um recordatório de 24 horas. Análises incluíram determinação do coeficiente de concordância, correlação intraclasse, coeficiente kappa ajustado, e testes de Wilcoxon e Kruskal-Wallis.

Resultados: o coeficiente de concordância foi $88 \%$ (transporte para escola) e $68 \%$ (atitude relativa às atividades físicas), enquanto o coeficiente de correlação intraclasse foi 0,85 para medida geral de atividade física. Utilizando relato de pais/professores, crianças foram classificadas em três grupos de atividade física (baixo/médio/alto), observando-se que os escores DAFA foram significativamente diferentes entre estes. Quanto às medidas de consumo alimentar, observou-se $80 \%$ de concordância entre aplicações do DAFA. Convergência de medidas interinstrumentos foi substancial/moderada em 17 itens alimentares.

Conclusões: o DAFA permite coletar medidas de atividade física e consumo alimentar de crianças com boa reprodutibilidade e moderada evidência de validade. Palavras-chave Atividade física, Ingestão de alimentos, Validade, Reprodutibilidade dos testes, Questionários, Criança 


\section{Introduction}

One of the main difficulties to accomplish studies, on a population based scope, related to the practice of physical activities and food patterns in schoolchildren is the scarcity of reasonably accurate data collection tools. ${ }^{1,2}$ Physical activities in children can be obtained through the use of cardiac frequency monitors, movement sensors, direct observation, the doubly labeled water method and self-reports (interviews, diaries and questionnaires).2,3 Population food intake patterns have been assessed by dietary history methods, recordatory methods, records, questionnaires on food intake frequency and observations. ${ }^{1}$ In general, available methods to measure these variables are limited and more accurate tools are not adequate for population based studies, for which, the use of questionnaires have been the most usual option due to its low cost and convenient management.

The interest for adequate tools to research exposure to health risks resulting from behavior, specially among schoolchildren, is justified by a set of factors: there are evidences suggesting that the assimilation of different behaviors resulting in risk to health, specially food habits take place in childhood and adolescence, 4,5 the promotion of healthy behaviors, such as physical activities in childhood and adolescence seem to produce long term benefits, 6 at this time children are too young to self-report or to fill meal frequency questionnares, 7 and parents or caretakers are not able to provide complete information on food intake during school hours. 8

The small number of comprehensive studies focusing the school age population, from seven to ten years old, is due in part to the lack of valid and easily manageable tools. In Brazil there are few reports on studies of this type and the existing ones have constraints related to the quality of the tools used with unverified accuracy and reproducibility. 9

This considerable gap in knowledge has encouraged the development of the physical activity and food intake day questionnaire. DAFA is a tool designed to obtain physical activities and food intake assessment in children from seven to ten years old. In this study the objective was the description of development and the assessment of test-retest reproducibility and concurrent validity of the DAFA questionnaire.

\section{Methods}

The DAFA validation study is part of an integrated research project, introduced in 2002 with the main objective of determining prevalence and factors associated to child obesity in Florianópolis, Santa Catarina, Brazil. This is a comprehensive project involving researchers of the Nutrition and Pediatrics Department of the Federal University of Santa Catarina and two other research groups. Studies conducted to design and validate DAFA consist in the initial phases of this project.

This study has been approved by the Ethics Committee for research involving humans of the Federal University of Santa Catarina. Parents of all participating children signed a free and informed consent form.

DAFA is a structured questionnaire with answers based on the choice of physical activities and food intake (Figure 1). It was developed with the purpose of obtaining information related to school children aged from seven to ten years old concerning these variables on a typical week day. The term "typical week day" in the application of the questionnaire was used to determine physical activities accomplished and food consumed in the majority of week days (from monday to friday).

In designing this tool, three studies were performed in independent focal groups developed by a multidisciplinary staff comprised of a physical education teacher, nutritionists, pediatricians and pedagogues. The first and second focal groups were conducted to respectively identify the types of physical activities and the most common food consumed by children in this age group. In the food list availability and menu used in public schools, food considered healthy and not healthy were included according to current consumption standards, following nutritional advice. The third study was performed to discuss the type of language and format (written and visual) of the questionnaire considering the curricular and cognitive phase of the children. Quantitative information on time expended in physical activities, frequency or estimates of food quantity were not included in the questionnaire, for other studies have suggested that time, periodicity, intensity and quantity are concepts that may not be fully developed in children of this age group. ${ }^{5-7}$

A choice was then made to design an illustrated questionnaire enabling to measure, based on the choice of physical activities, meals and types of food on a typical week day. The illustration of the tool was made by a specialized company. Following results analysis of the pilot phase of the study, the questionnaire was submitted to graphic adjustments and an application protocol was standardized to train interviewers. The final version structure of DAFA 

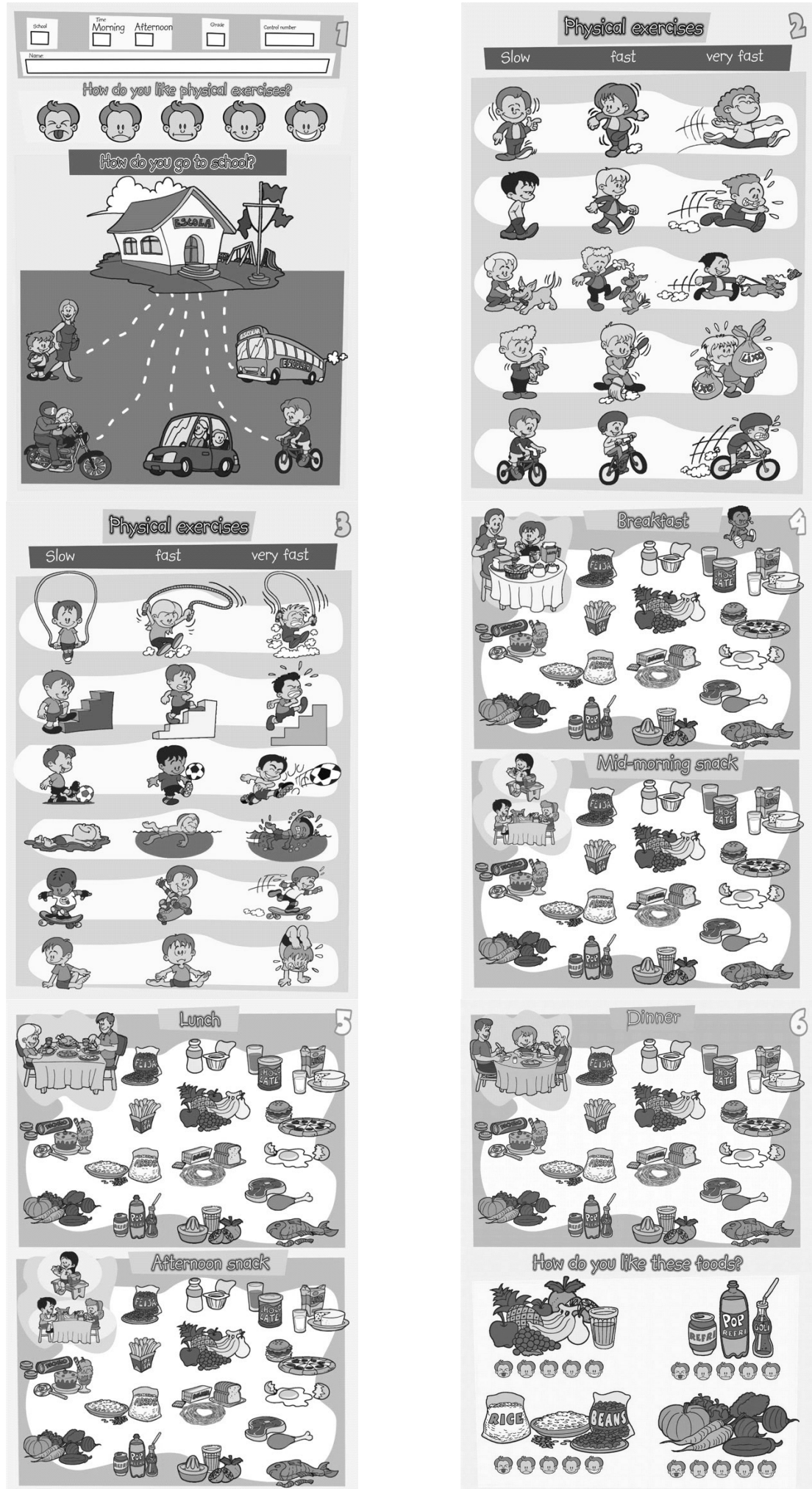

How do you likke these foøds?

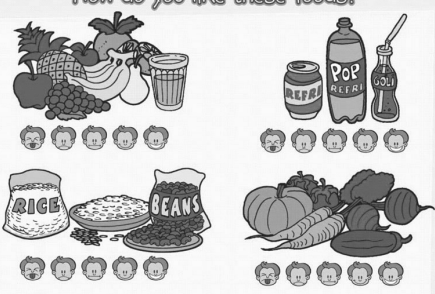


contained six pages with 50 colored illustrations. The first three pages of the questionnaire are related to physical activities measures and the three last ones to food.

In the section of physical activities of DAFA there are four types of measures that can be derived from the information provided by the students:

a) Attitude (taste) for physical activities (named by the school children "exercises"), referred by the subjects as a base for an hedonic scale with five categories of facial expressions;

b) Type of transportation from home to school enabling the identification of subjects using active forms (walking and pedaling) to commute in comparison with those using motor vehicles;

c) Intensity of physical activities accomplished during a normal day. Measures are reported by the subjects through a hedonic scale with three illustrations, in the extreme left are the slow physical activities (light) and in the extreme opposite, activities that are performed with more speed (vigorous). Because there are eleven activities to be chosen by the students, a predominant tendency could indicate the intensity level of the usually performed activities;

d) General level of physical activities determined based on the sum of scores related to activities subjects reported to perform, with the possibility of computing three levels of intensity for each activity. This option resulted from observation throughout the focal group study that children can, on a typical day, perform the same activity, in different periods, but that in each period prevalent intensity may differ. To obtain the score representing general physical activities, activities reported were pondered with weight assigned one for light intensity activities, three for moderate intensity activities and nine for those of vigorous activities (very fast). Pondering in this case represented an approximation of the metabolic cost for the intensity of the activities performed, already used in similar studies. 10,11 Adopting such criteria, the maximum score to be achieved is 187 points.

In the second section of the questionnaire, information related to food intake enabled information on:

a) Choices of food groups and food consumed on a typical week day;

b) Quantitative analysis of food events through the classification of meals and snacks according to the combination of food groups, with different nutrients' sources, according to the Food-Based Classification of Eating Episodes Model (FBCE). 12 Table 1 depicts the FBCE model adapted to DAFA. The nutritional profile of food groups is presented as a qualitative description of energetic, nutritional density and of the sources of the main nutrients. According to the model exhibited in this table, an event can be considered a meal when it is comprised by, at least, two groups of high nutritional density food $(\mathrm{A}+\mathrm{B}+\mathrm{C}$ or $\mathrm{A}+\mathrm{B}$ or $\mathrm{A}+\mathrm{C}$ or $\mathrm{B}+\mathrm{C})$. Snacks are defined as events comprised with only one food group of high nutrition density (A or B or C);

c) It's also possible to identify subjects not eating the main meals of the day and the ones who do not eat breakfast, an important indicator of food behavior; 12

d) Attitudes (taste, preferences) of the subjects related to the four food groups: two of sweet flavor (pop soda and fruit), one of unique or acid flavor (vegetables) and another of a salty flavor (beans and rice), a measure referred by the subjects based on a hedonic scale with five categories of facial expressions.

To assess test-retest consistency measures indicators (reproducibility) and concurrent value, a study was performed by 69 students ( 35 girls) from the first to the fourth grade of elementary school recruited on a public school (up to 20 students per class) from Florianopolis. The school was intentionally selected by a basic school unit geographically close to the schools where a survey team previously performed focal studies supporting the designing of the questionnaire. In this school, a class for each grade was randomly selected. All students of the four classes chosen filled the questionnaire. Data was collected in August, 2002.

Consistency of physical activity and meals obtained through DAFA was tested in two applications ( $\mathrm{T} 1$ and $\mathrm{T} 2$ ) of the questionnaire to the same group of school children. As in Edmunds and Ziebland's study, ${ }^{8}$ the interval between applications was of two weeks performed in the same day of the week by the same interviewers.

Questionnaire administration was performed in the classroom by two research assistants with the help of the students' teacher. While one of the research assistant using an amplified format (poster) of each of the six pages of the questionnaire, instructing on how to fill the questionnaire, the students' teacher and another survey assistant circulated in the classroom to help the children and encourage answers. In the first place the questionnaire was introduced to the children with a brief exhibition of all sections highlighting the required information related to what is usually performed in the majority of week days. Following instructions with words, gestures, movements and contexts, the assistants and the teacher helped the children answer in each session. 
Food groups of physical activity and food intake day (DAFA) related to nutritional density and food composition.

\begin{tabular}{|c|c|c|c|}
\hline Food groups & Food & Nutritional density & Nutrition composition \\
\hline \multicolumn{4}{|l|}{ A } \\
\hline Animal protein & $\begin{array}{l}\text { Beef, chicken, pork, fish, } \\
\text { shrimp, seafood, eggs, yogurt, } \\
\text { milk derived food, cheese, } \\
\text { chocolate milk }\end{array}$ & $\begin{array}{l}\text { High density of } \\
\text { nutrients and energy }\end{array}$ & $\begin{array}{l}\text { Animal protein and fat, } \\
\text { iron, zinc, calcium }\end{array}$ \\
\hline \multicolumn{4}{|l|}{ B } \\
\hline Amylum & $\begin{array}{l}\text { Break, crackers, pasta, beans, } \\
\text { rice }\end{array}$ & $\begin{array}{l}\text { High density of } \\
\text { nutrients and energy }\end{array}$ & $\begin{array}{l}\text { Amylum, vegetal } \\
\text { proteins, fibers }\end{array}$ \\
\hline \multicolumn{4}{|l|}{ C } \\
\hline Vegetable and fruits & Vegetable, fruits, fruit juices & $\begin{array}{l}\text { High density of } \\
\text { nutrients, low } \\
\text { ascorbic acid }\end{array}$ & $\begin{array}{l}\text { Fibers, carotenoid, } \\
\text { energetic density }\end{array}$ \\
\hline \multicolumn{4}{|l|}{ D } \\
\hline Sweets & $\begin{array}{l}\text { Filled cookies, handmade or } \\
\text { fair purchased cookies, cakes, } \\
\text { pastry, deserts, honey, ice- } \\
\text { cream, chocolates }\end{array}$ & $\begin{array}{l}\text { High energetic and } \\
\text { fat density, low } \\
\text { nutrients density }\end{array}$ & $\begin{array}{l}\text { Amylum, sugar, animal } \\
\text { and vegetal fat }\end{array}$ \\
\hline \multicolumn{4}{|l|}{ E } \\
\hline $\begin{array}{l}\text { Soft drinks and kool- } \\
\text { aids }\end{array}$ & & $\begin{array}{l}\text { High energetic density } \\
\text { and low nutrients } \\
\text { density }\end{array}$ & Sugars \\
\hline \multicolumn{4}{|l|}{$\mathrm{F}$} \\
\hline Fried food & $\begin{array}{l}\text { French fries, fried food, pizza, } \\
\text { hamburger }\end{array}$ & $\begin{array}{l}\text { High energetic and } \\
\text { high animal and } \\
\text { vegetal fats }\end{array}$ & Saturated fats \\
\hline
\end{tabular}

Adapted from: Lennernãs M, Andersson I. Food-based classification of eating episodes. Appetite. 1999.12

Validity evidences of the questionnaire to obtain physical activities measures were determined through data comparison obtained through DAFA and of one structured questionnaire, filled by parents and teachers, in which they independently classified the level of the child's physical activity, respectively during the period when they were at home and at school. Children considered "active" were the ones whose parents (physical activities at home) and teachers (physical activities at school) reported being physically more active in comparison to other children of the same age and gender. The children rated by parents or teachers as being less physically active were classified as "not active". Following, an assessment was made to determine whether these groups ("active"/"not active") rated by parents and teachers had significant general score differences as compared with the general physical activity score obtained by the DAFA questionnaire.

Food intake measures validation was performed by comparing DAFA's data and their relation with the data furnished by the children through a 24 hour recordatory. Students from the Nutrition and Medical School of the Federal University of Santa Catarina were trained to use the food recordatory method of 24 hours through an individual interview and according to the "step by step" technique. 13

All the same, the DAFA questionnaire enables the obtainment of different scales' measures, not only related to physical activities but related to food intake as well. Therefore, in this study, reproducibility and validity indicators required the use of 
different analysis procedures. For practical reasons, the use of high tech reference methods was not feasible.

Physical activities in continuous scale were obtained by pondering physical activities reported by DAFA, according to the level of intensity (slow, fast and very fast). Other measures obtained included the type of transportation in commuting from home to school (nominal) and the attitude related to exercises (ordinal). To validate food standard measures, analysis consider the convergence related to the consumption of 14 types of food in five meals (breakfast, snack, lunch, afternoon snack and dinner), with data being grouped for three periods per day (morning, afternoon and evening).

In case of continuous scale measure, intraclass correlation coefficient $(R)$ to verify measure consistency (reproducibility) in two applications (T1 and T2) of DAFA was used. Wilcoxon signal scoring test for paired samples (the non-parametric " $t$ " test for dependent samples version) was used in comparing the physical activities obtained in the two DAFA applications.

For nominal or ordinal scale of measure analysis the concordance coefficient (\%) was used. Additionally, data were compared item per item to determine absolute, relative (\%) and kappa (k) coefficients. Due to the asymmetry of data distribution in the contingency table (example: constant values in one of the tests) compromising interpretation and calculation of kappa, 14 also resorted to the determination of a kappa coefficient adjusted for prevalence and bias named Prevalence And Bias Adjusted Kappa (PABAK) according to the literature.14,15 The kappa as well as the PABAK coefficients stand out from relative concordance because they are coefficients adjusted to random concordance statistical change.

In general, $\mathrm{k}$ values (or PABAK) go from 0 (no concordance) to 1 (perfect concordance), but negative values are possible. PABAK and k determination was used in the assessment of measures consistency as well as in the convergence of PAFID obtained measures and reference methods (concurrent validity). According to literature suggestion 16 the following criteria of kappa and PABAK values interpretation were adopted: poor $(\leq 0,20)$; weak (0.21-0.4); moderate (0.41-0.6); substantial (0.61$0.8)$; and good (>0.8).

The Kruskal Wallis $(\mathrm{H})$ test, a non-parametric equivalent for variance analysis was used as well. Analyses were performed through the SPSS software (version 10) and an electronic spreadsheet developed by Mackinnon 17 to analyze nominal scale measures concordance. StudySize 2.0 software was used to calculate the statistical power of the analyses performed.

The critical level for nullity hypothesis rejection was fixed in $p<0.05$. Once this parameter and analyses sample size were considered, it was determined that the statistical power of the analyses ranked over $80 \%$ for the calculation of intraclass coefficients and over $72 \%$ for kappa and adjusted kappa.

\section{Results}

It was determined that questionnaire's items related to the type of transportation used to commute from home to school and the attitude towards physical activities enabled the obtainment of relatively consistent measures of these variables between DAFA's applications with the concordance coefficients of $88 \%$ and $68 \%$ respectively. On Table 2 reproducibility rates are depicted related to the eleven types of physical activities included in DAFA.

Considering the Wilcoxon signal scoring test it was determined that the measure of two types of physical activities ("skating" and "playing with the dog") were significantly higher in T2 when compared to T1. With the exception of the item on swimming, with less measure stability $(\mathrm{R}=0.33$; $p=0.05$ ), intraclass correlation coefficients were verified between DAFA item determined to be statistically significant $(p<0.05)$. Grouping information in determining a general coefficient for physical activities, intraclass coefficient was higher still $(R=0.85$; 95\%CI:0.76-0.91) and no significant difference was determined between the first (median $=64.9$ points; $\mathrm{DP}=28.4$ ) and the second (median=68.0 points; $\mathrm{DP}=31.1)$ DAFA application. These results suggest that DAFA allowed for the obtainment of physical activities measures which in general were relatively consistent in $\mathrm{T} 1$ and $\mathrm{T} 2$.

To obtain concurrent validity indicators, the level of physical activity of these subjects was measured by two methods: information collected through DAFA (continuous scale) and a derived classification of the information furnished by parents and teachers (measure in ordinal scale, named proxy). Using approximation measures, three groups with presumed difference in physical activities levels were formed. These groups had a significant statistical difference $(\mathrm{H}=7.42 ; p<0.05)$ in median scores, calculated on the basis of DAFA's information. The group with lower physical activity $(n=26)$, intermediate $(n=27)$ and higher $(n=16)$ presented respectively 
Physical activities measures in two applications ( $\mathrm{T} 1$ and $\mathrm{T} 2$ ) of the questionnaire of a typical physical exercise and food intake day (DAFA) in 69 children.

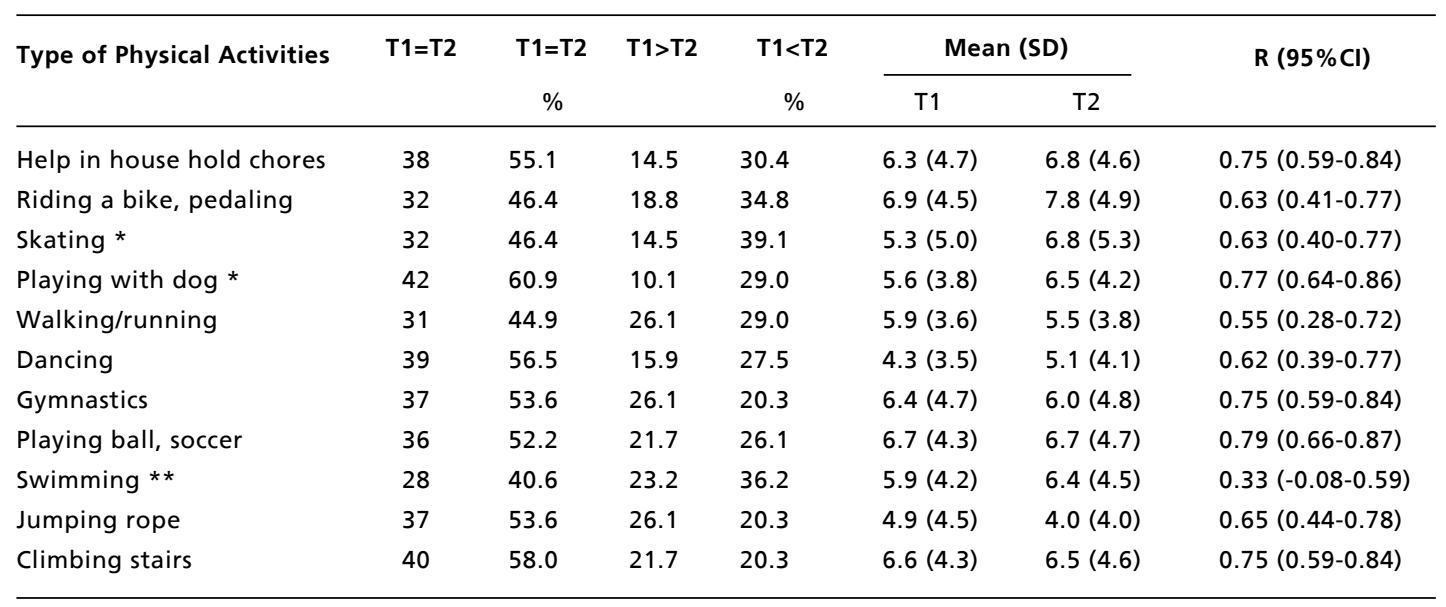

* Significant difference between T1 and T2 $(p<0.05)$ considering the ranking test of Wilcoxon, ** $\mathrm{R}$ value was not statistically significant according to the confidence interval limits.

the following median scores : 16.8, 26.1 and 31.7.

Additionally, subject classification in two groups (more active/less active) according to the level of physical activity reported by the parents and measured through DAFA was used. The concordance coefficient was $74 \%$ with kappa $=0.28(p<0.05)$. These results suggest that DAFA depicts modest concurrent validity coefficients against approximation measures to assess children's physical activities level.

In general the results depicted by Table 3 indicate that there is a concordance of approximately $80 \%$ between the information furnished in $\mathrm{T} 1$ and $\mathrm{T} 2$. In the assessment of relative concordance, the item presented less measure consistency between applications was the consumption of pizza, at night; the item with a higher measure consistency were the ones indicating the intake of bread and vegetables in the morning.

The statistical kappa values indicate a moderate and substantial concordance between information related to food consumption in the applications of $\mathrm{T} 1$ and T2 of DAFA. Of the 42 items verified for food intake measure consistency in only three the kappa value was poor. As for PABAK values it was noted that no coefficient was lower than 0.3 .

Concordance between measures obtained through the application of the DAFA questionnaire and the 24 hour recordatory was used for concurrent validity indicators analysis. In general concordance related coefficient between the tools varied approxi- mately 42 to $92 \%$ according to the type/group of food and the meal in which this food intake was reported. The results depicted on Table 4 suggest that approximately three in every four subjects reported convergent information in the two questionnaires. The higher measure concordance was noted in relation to the vegetables intake report in the morning (91.9\%); the lowest related to the consumption of bread in the afternoon $(41.9 \%)$. Independently of the hour of the meals, measures derived from the two questionnaires were more convergent in relation to the consumption of: beans, rice, yogurt, eggs and fish.

Kappa coefficients over 0.20 were noted only in relation to yogurt, fruit, juices, soft drinks and eggs. It's important to emphasize the in many of the items in Tables 3 and 4 there is a correspondence between the low proportion of subjects reporting food consumption and kappa coefficients, equally low. Particularly in these cases, it is possible that PABAK values better represent the existing convergence between the questionnaires.

The assessment of PABAK values determined that nine of the items presented substantial concordance, eight moderate concordance; ten weak concordance; and the other 15 items presented poor concordance.

This study also determined that with the supervision of two interviewers and the help of the teacher of the class, the majority of the children $(n=43)$ was able to fill the questionnaire in approximately 40 to 50 minutes, this time requirement was a little more 
Table 3

Food intake measures comparison (T1 and T2) of the questionnaire of a typical physical activity and food intake day (Dafa) $(n=69)$.

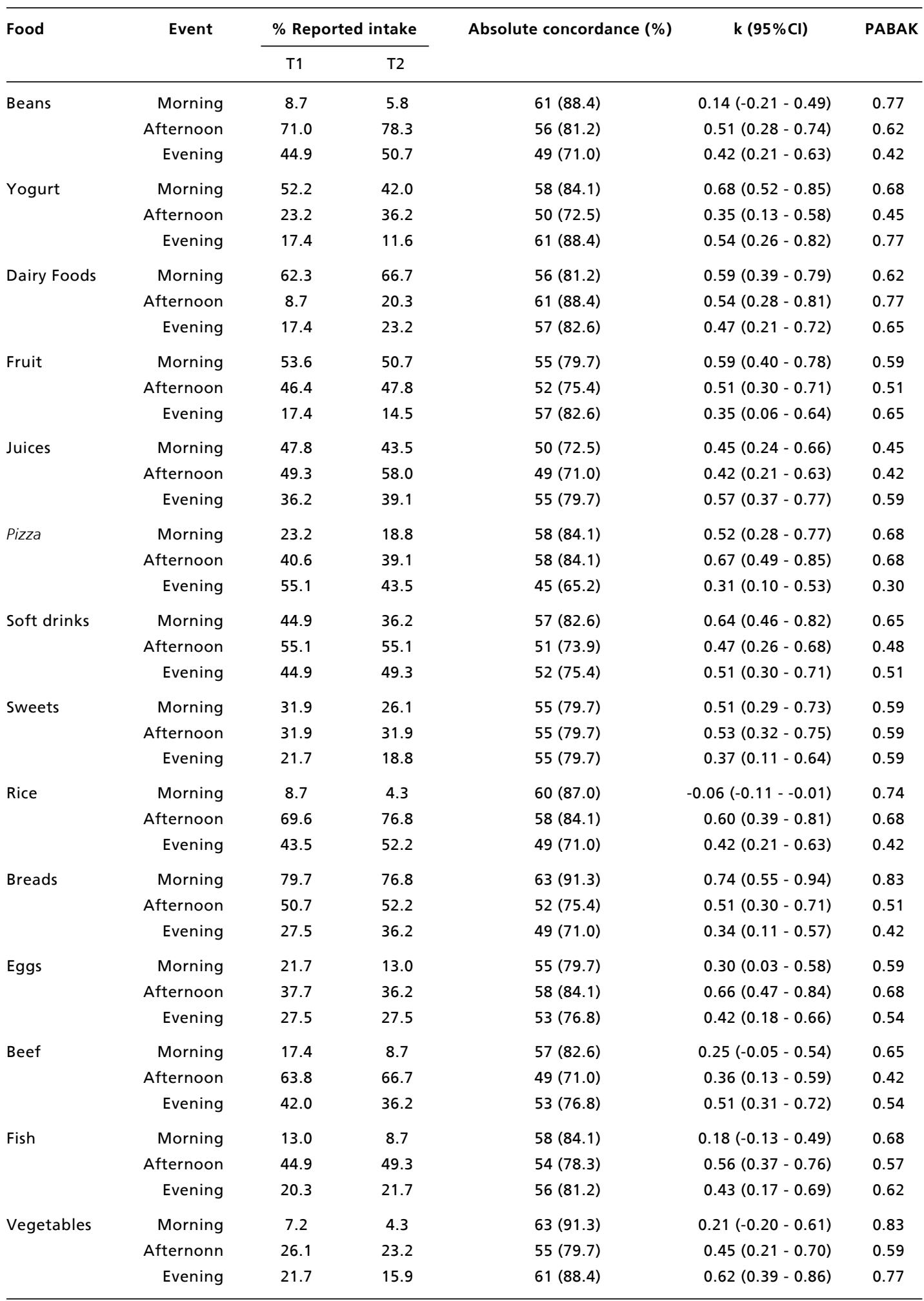


Comparison of food intake measures through the questionnaire of a typical physical activity and food intake day (DAFA) according to a 24 hour food recordatary $(n=69)$.

\begin{tabular}{|c|c|c|c|c|c|c|}
\hline \multirow[t]{2}{*}{ Food } & \multirow[t]{2}{*}{ Event } & \multicolumn{2}{|c|}{$\%$ Intake reporte } & \multirow[t]{2}{*}{ Absolute concordance (\%) } & \multirow[t]{2}{*}{ k $(95 \% \mathrm{Cl})$} & \multirow[t]{2}{*}{ PABAK } \\
\hline & & T1 & $\mathrm{T} 2$ & & & \\
\hline \multirow[t]{3}{*}{ Beans } & Morning & 9.7 & 0.0 & $56(90.3)$ & $0.00(0.00-0.00)$ & 0.81 \\
\hline & Afternoon & 71.0 & 74.2 & $42(67.7)$ & $0.19(-0.07-0.45)$ & 0.35 \\
\hline & Evening & 45.2 & 24.2 & $35(56.5)$ & $0.08(-0.14-0.31)$ & 0.13 \\
\hline \multirow[t]{3}{*}{ Yogurt } & Morning & 51.6 & 9.7 & $34(54.8)$ & $0.12(-0.02-0.26)$ & 0.10 \\
\hline & Afternoon & 22.6 & 8.1 & $49(79.0)$ & $0.22(-0.05-0.50)$ & 0.58 \\
\hline & Evening & 11.3 & 6.5 & $53(85.5)$ & $0.11(-0.21-0.43)$ & 0.71 \\
\hline \multirow[t]{3}{*}{ Dairy products } & Morning & 61.3 & 80.6 & $40(64.5)$ & $0.18(-0.05-0.41)$ & 0.29 \\
\hline & Afternoon & 9.7 & 27.4 & $41(66.1)$ & $-0.07(-0.25-0.11)$ & 0.32 \\
\hline & Evening & 17.7 & 58.1 & $29(46.8)$ & $0.04(-0.13-0.20)$ & -0.06 \\
\hline \multirow[t]{3}{*}{ Fruits } & Morning & 50.0 & 25.8 & $37(59.7)$ & $0.19(-0.02-0.41)$ & 0.19 \\
\hline & Afternoon & 43.5 & 40.3 & $40(64.5)$ & $0.27(0.03-0.51)$ & 0.29 \\
\hline & Evening & 14.5 & 17.7 & $46(74.2)$ & $0.05(-0.22-0.31)$ & 0.48 \\
\hline \multirow[t]{3}{*}{ Juices } & Morning & 41.9 & 11.3 & $41(66.1)$ & $0.23(0.04-0.41)$ & 0.32 \\
\hline & Afternoon & 43.5 & 67.7 & $31(50.0)$ & $0.04(-0.18-0.26)$ & 0.00 \\
\hline & Evening & 32.3 & 30.6 & $37(59.7)$ & $0.07(-0.19-0.32)$ & 0.19 \\
\hline \multirow[t]{3}{*}{ Pizza } & Morning & 21.0 & 1.6 & $50(80.6)$ & $0.12(-0.09-0.33)$ & 0.61 \\
\hline & Afternoon & 37.1 & 3.2 & $41(66.1)$ & $0.11(-0.03-0.25)$ & 0.32 \\
\hline & Evening & 54.8 & 12.9 & $28(45.2)$ & $-0.02(-0.18-0.13)$ & -0.10 \\
\hline \multirow[t]{3}{*}{ Soft-drinks } & Morning & 43.5 & 4.8 & $38(61.3)$ & $0.12(-0.01-0.26)$ & 0.23 \\
\hline & Afternoon & 53.2 & 35.5 & $39(62.9)$ & $0.27(0.05-0.49)$ & 0.26 \\
\hline & Evening & 41.9 & 17.7 & $41(66.1)$ & $0.24(0.03-0.46)$ & 0.32 \\
\hline \multirow[t]{3}{*}{ Sweets } & Morning & 29.0 & 8.1 & $45(72.6)$ & $0.15(-0.07-0.38)$ & 0.45 \\
\hline & Afternoon & 29.0 & 24.2 & $37(59.7)$ & $-0.03(-0.27-0.21)$ & 0.19 \\
\hline & Evening & 19.4 & 9.7 & $46(74.2)$ & $-0.02(-0.24-0.20)$ & 0.48 \\
\hline \multirow[t]{3}{*}{ Rice } & Morning & 8.1 & 1.6 & $56(90.3)$ & $-0.03(-0.07-0.02)$ & 0.81 \\
\hline & Afternoon & 69.4 & 85.5 & $42(67.7)$ & $0.11(-0.13-0.35)$ & 0.35 \\
\hline & Evening & 40.3 & 24.2 & $36(58.1)$ & $0.07(-0.17-0.30)$ & 0.16 \\
\hline \multirow[t]{3}{*}{ Breads } & Morning & 80.6 & 82.3 & $45(72.6)$ & $0.09(-0.18-0.37)$ & 0.45 \\
\hline & Afternoon & 51.6 & 64.5 & $26(41.9)$ & $-0.17(-0.41-0.06)$ & -0.16 \\
\hline & Evening & 25.8 & 62.9 & $33(53.2)$ & $0.17(-0.01-0.34)$ & 0.06 \\
\hline \multirow[t]{3}{*}{ Eggs } & Morning & 17.7 & 4.8 & $50(80.6)$ & $0.07(-0.17-0.32)$ & 0.61 \\
\hline & Afternoon & 33.9 & 4.8 & $44(71.0)$ & $0.18(0.00-0.36)$ & 0.42 \\
\hline & Evening & 25.8 & 9.7 & $48(77.4)$ & $0.26(0.00-0.52)$ & 0.55 \\
\hline \multirow[t]{3}{*}{ Beef } & Morning & 14.5 & 0.0 & $53(85.5)$ & $0.00(0.00-0.00)$ & 0.71 \\
\hline & Afternoon & 62.9 & 80.6 & $37(59.7)$ & $0.04(-0.19-0.27)$ & 0.19 \\
\hline & Evening & 40.3 & 25.8 & $33(53.2)$ & $-0.03(-0.27-0.20)$ & 0.06 \\
\hline \multirow[t]{3}{*}{ Fish } & Morning & 12.9 & 0.0 & $54(87.1)$ & * & 0.74 \\
\hline & Afternoon & 38.7 & 3.2 & $36(58.1)$ & $-0.06(-0.15-0.02)$ & 0.16 \\
\hline & Evening & 17.7 & 0.0 & $51(82.3)$ & * & 0.65 \\
\hline \multirow[t]{3}{*}{ Vegetables } & Morning & 6.5 & 1.6 & $57(91.9)$ & $-0.03(-0.07-0.02)$ & 0.84 \\
\hline & Afternoon & 21.0 & 66.1 & $28(45.2)$ & $0.08(-0.08-0.23)$ & -0.10 \\
\hline & Evening & 16.1 & 22.6 & $46(74.2)$ & $0.18(-0.10-0.46)$ & 0.48 \\
\hline
\end{tabular}

* Data collected in the 24 hour recodatary remained constant (intake was not reported by none of the subjects). kappa coefficient calculation was not possible. PABAK in this case is the only indicator that can be analyzed. 
extended in the first and second grades and less extended in the third and fourth grades.

\section{Discussion}

This study presented the development of the DAFA plus reproducibility and concurrent validity coefficients. Among the constraints of this tool, the following can be names: a) this is a structured questionnaire not allowing for the inclusion of food or drinks consumed out of the schedule of the five meals or other not reported physical activities; b) it does no allow for quantitative estimated of energetic burn and intake and the number of food portions; c) there is not a notion of limited periodicity (for example, yesterday or the week before); and d) each child could have a different interpretation of the notion of a "typical week day, in addition, the measure related to a "typical day" is not equivalent to the behavior noted in all of the week days.

Nevertheless, all these limitations are common in questionnaires used to reach the objectives of a population based survey comprising the age bracket from 7 to 10 years old. It is difficult, both in terms of cost, time and operation, the accomplishment of interviews with school children and their parents to obtain information on the quantity of the food consumed and physical activities performed. The fact of not delimiting a specific week day was made on purpose for in the study of focal groups; the use of the expression "in the majority of week days" was considered more representative of a "typical week day" than "yesterday", thus facilitating the application. It's an assumption that children reported activities and food representative of a day close to the day of the interview, for literature has determined that in this age group, their ability to recall activities or food intake related to a long period of time, is limited. 7

Bread consumption was the item presenting less measure convergence between the questionnaires. In part, this could be due because in the preliminary version of DAFA, used in this study, bread was only represented in its absolute form. Nevertheless, because children tend to consume bread in the form of sandwiches and as a complement, they could have suppressed the information because of the lack of option in the questionnaire. Adjustments in DAFA were then performed to graphically represent a burger type sandwich in the group of pizza and pastry. As a result, the submission protocol was refined as well to instruct the children of the way to mark bread consumption, with sweets or with cheese and/or ham; for example, they were asked to mark the figure corresponding to the group of bread and complements (group of sweets, of milk derived food, meat derived food). Similar instructions were given for other preparations, the example being meals based on pasta or rice with vegetables or meats. In the final version of the questionnaire, the need to include chocolate milk was also determined, as an item in itself, for when comparing DAFA's data to the food recordatory data, it was noted that children tend not to include chocolate milk with milk consumption. It's important to emphasize the fact that these changes in the questionnaire were performed following this study as a result of the findings determined by it.

Although the 24 hour recordatory method and approximation measures (information on physical activities provided by parents and teachers through questionnaires) are intensively used reference methods in concurrent validation studies, the literature determines that their validity if limited by the ability of the subjects (parents and or teachers) in recalling and reporting food intake 18 and physical activities. 19 These constraints may have contributed to reduce measures concordance obtained by DAFA and reference methods used in this study. It should also be mentioned that physical activities scores presented marked variability among the subjects which may have contributed to the inter-questionnaires convergence reduction.

It is difficult to compare between validation studies results, specially because the measures are based on different criteria and time limitations. A food consumption frequency questionnaire, similar to DAFA has been successfully validated in comparison to consumption observations with school children from the third to the sixth grade of elementary school. The questionnaire (Go for Health Questionnaire) was designed in a format of a list with 89 food illustrations and checking columns for breakfast, lunch, dinner and snacks. In this validation study, the authors compared data obtained in the questionnaire application in class with 24 hour food recordatory. A general concordance of $83.3 \%$ was reported, but no statistical analysis was possible due to the limited number of subjects in the sample (only seven). 20

Koehler et al., 18 in a validation study of a questionnaire designed to measure (based on the selection) consumed food, noted results similar to ours. The difference is that the questionnaire tested by these authors related to the assessment of children from 10 to 14 years old, whilst DAFA was tested on a younger and less schooled group and this type of group self-reports are particularly more difficult. 
Edmunds and Ziebland 8 recently presented the development and validation of a questionnaire similar to DAFA to measure fruits and vegetables intake in children from six to nine years old. The kappa coefficients determined by this study ranged approximately on 0.5 but were determined by measures comparison reported by the subjects with the monitoring of the researchers, a reference method that is more precise than the 24 hour recordatory method. The studies comparing the data resulting from the monitoring technique and the questionnaires determined a concordance between $73.4 \%$ and $86.3 \%$ for physical activity, ${ }^{2}$ while for fruit and vegetables intake data a concordance of $68.5 \%$ and $74 \%$ was established. ${ }^{13}$

Some studies suggest that only children over 10 years old are able to produce valid information from self-report on physical activities and food intake 5,19 while others refer that starting at eight years old there's a rapid increase of the children's ability of food intake self-reporting. 7 The experience with the DAFA application determined that this questionnaire seems to be adequate even when applied to first graders of elementary school and that could be the result of the structured and graphic representation of the activities and exposure of the food in sequenced meals. The questionnaire was well received by the majority of teachers and children who considered it to be attractive and with evident educational value, an important feature of tools such as this. In comparison with the questionnaires used with adults, "40 to 50 minutes" can seem to be a lot of time to fill a questionnaire, nevertheless, because this is to be done with small groups of students (class) and not individually we believe that this will not compromise the use of the questionnaire.

Considering that children participating of the

\section{References}

1. McPherson RS, Hoelscher DM, Alexander M, Scanlon KS, Serdula MK. Dietary assessment methods among schoolaged children: validity and reliability. Prev Med. 2000; 31: S11-S33.

2. Sirard JR, Pate RR. Physical activity assessment in children and adolescents. Sports Med. 2001; 31: 439-54.

3. Conway JM, Seale JL, Jacobs Jr DR, Irwin ML, Ainsworth BE. Comparison of energy expenditure estimates from doubly labeled water, a physical activity questionnaire, and physical activity records. Am J Clinical Nutr. 2002; 75: 519-25.

4. Baranowski T, Simons-Morton BC. Dietary and physical reproducibility and validity study were from public schools, reproducibility and validity indicators depicted in the section of results, should be interpreted with caution. Evidence disclosed by this paper suggest that DAFA, in general, presented moderate coefficients not only related to test retest consistency (reproducibility) and concurrent validity as well. It is believed that DAFA can be an acceptable tool for epidemiological studies aiming at general indicators of the practice of physical activities and food intake in children from seven to ten years old.

\section{Acknowledgements}

To the children, parents and teachers participating of the research; to Sanlina Barreto Hulse, Nutritionist of the Municipal Education Secretariat of Florianópolis; to Cristiane Teixeira Siementcoski, Pedagogue of the Colégio Menino Jesus in Florianópolis; to Doctor Maria Marlene de Souza Pires, Professor of Pediatric Department of the Federal University of Santa Catarina; to the students of the Undergraduate and Graduate Programs in Nutrition (Adriana Lobo, Cláudia Soar, Natália Trois Gomes Monteiro, Caroline Spileri, Heide Gauche, Marta de Barros Pinto, Cláudia Soar), Medicina (Maria Emília Baião Silva) and Physical Education (Mathias Loch) who helped in the collection of data and, to the Foudation of Science and Technology of the State of Santa Catarina [(Fundação de Ciência e Tecnologia do Estado de Santa Catarina (FUNCITEC)] for dunding the project (application 63/2002) and to the Health Secretariat of the City of Florianopolis for logistical support. activity assessment in school-aged children: measure issues. J School Health. 1991; 61: 195-7.

5. Goodwin RA, Brullé D, Junkins EA, Dubois S, Beer-Borst $S$. Development of a food and activity record and a portionsize model booklet for use by 6-to 17-year olds: a review of focus-group testing. J Am Diet Assoc. 2001; 101: 926-8.

6. Mikkila V, Rasanen L, Raitakari OT, Pietinen P, Viikari J. Longitudinal changes in diet from childhood into adulthood with respect to risk of cardiovascular diseases: the cardiovascular risk in young finns study. Eur J Clin Nutr. 2004; 58: $1038-45$. 
7. Baranowski T, Domel SB. A cognitive model of children's reporting of food intake. Am J Clin Nutr. 1994; 59 (Suppl): S212-S7.

8. Edmunds LD, Ziebland S. Development and validation of the day in the life questionnaire (DILQ) as a measure of fruit and vegetable questionnaire for 7-9 years olds. Health Educ Res. 2002; 17: 211-20.

9. Lopes AS, Pires-Neto CS. Estilo de vida de crianças com diferentes características étnico-culturais do Estado de Santa Catarina, Brasil. Rev Bras Ativ Fis Saúde. 2001; 6: 6-16.

10. Aadahl M, Jørgensen T. Validation of a New Self-Report Instrument for Measuring Physical Activity. Med Sci Sports Exerc. 2003; 35: 1196-1202.

11. Grey M, Berry D, Davidson M, Galasso P, Gustafson E, Melkus G. Preliminary testing of a Program to Prevent Type 2 Diabetes Among High-Risk Youth. J Sch Health. 2004; 74: 10-5.

12. Lennernãs M, Andersson I. Food-based classification of eating episodes. Appetite. 1999; 32: 53-65.

13. Baxter SD, Thompson WO, Litaker MS, Guinn CH, Frye FHA, Baglio M, Shaffer NM. Accuracy of fourth-graders' dietary recalls of school breakfast and school lunch validated with observations: in-person versus telephone Interviews. J Nutr Educ Behav. 2003; 35: 124-34.
14. Cicchetti DV, Feinstein AR. High prevalence but low kappa: II. Resolving the paradoxes. J Clin Epidemiol. 1990; 43: 551-8.

15. Byrt T, Bishop J, Carlin JB. Bias, prevalence and kappa. J Clin Epidemiol. 1993; 46: 423-9.

16. Petrie A, Sabin C. Medical statistics at a glance. London: Blackwell Science; 2000.

17. Mackinnon A. A spreadsheet for the calculation of comprehensive statistics for the assessment of diagnostic tests and inter-rater agreement. Comp Biol Med. 2000; 30: 127-4.

18. Koehler KM, Cunningham-Sabo L, Lambert LC, McCalman R, Skipper BJ, Davis SM. Assessing food selection in a health promotion program: validation of a brief instrument for American Indian children in the southwest United States. J Am Diet Assoc. 2000; 100: 205-11.

19. Welk GJ, Corbin CB, Dale D. Measure issues in the assessment of physical activity in children. Res Q Exerc Sport. 2000; 71 (2 Suppl): S59-S73.

20. Simons-Morton BG, Baranowski T, Parcel GS, O'Hara NM, Matteson RC. Children's frequency of consumption of foods high in fat and sodium. Am J Prev Med. 1990; 6: 218-27.

Received April 30, 2007

Final version submitted in June 4, 2007

Approved in July 6, 2007. 